\title{
PERAN KEMAJUAN TEKNOLOGI DALAM PERTUNJUKAN MUSIK
}

\author{
Sang Nyoman Satria Irnanningrat \\ Institut Seni Indonesia Yogyakarta \\ sangnyoman.satria@yahoo.com
}

\begin{abstract}
Abstrak
Musik merupakan suatu hasil karya seni bunyi dalam bentuk lagu atau komposisi musik yang mengungkapkan pikiran dan perasaan penciptanya melalui unsur-unsur musik yaitu irama, melodi, harmoni, bentuk dan struktur musik serta ekspresi sebagai satu kesatuan. Salah satu cara penyampaian musik yaitu melalui pertunjukan musik. Namun, perkembangan teknologi membuat pertunjukan musik secara langsung menjadi semakin jarang diminati oleh para penikmat musik. Selain itu, media pertunjukan musik secara langsung juga menjadi kian sempit bagi para musisi karena fenomena keberalihan cara menikmati musik dari waktu ke waktu. Tujuan dari penelitian ini adalah untuk mengetahui apa sajakah bentuk-bentuk penyebab matinya pertunjukan musik dilihat dari teori simulakra dari Jean Paul Baudrillard serta bagaimana efek Simulakra terhadap pertunjukan musik. Penelitian ini menggunakan metode kualitatif serta menerapkan pendekatan sosiologi. Dalam penelitian ini penulis memperoleh dan mengumpulkan data dengan dua cara, yaitu pengumpulan data melalui internet dan studi pustaka. Hasil dari penelitian ini menunjukkan bahwa perkembangan teknologi, seni menikmati musik melalui pertunjukan musik perlahan bergeser dan mulai hilang digantikan dengan alat-alat atau instrumen simulakra seperti kaset, $\mathrm{CD}$, VCD, Youtube, RBT, dan iTunes. Selanjutnya, simulakra juga membawa dampak yang signifikan terhadap matinya pertunjukan musik yaitu salah satunya adalah dehumanisasi atau suatu kondisi dimana manusia telah meninggalkan kodratnya sebagai manusia.
\end{abstract}

Kata kunci: musik, pertunjukan musik, simulakra.

\section{Pendahuluan}

Musik adalah cabang seni yang membahas dan menetapkan berbagai suara ke dalam pola-pola yang dapat dimengerti dan dipahami manusia. Musik berasal dari kata muse, yaitu salah satu dewa dalam mitologi Yunani kuno bagi cabang seni dan ilmu; dewa seni dan ilmu pengetahuan. Musik yang baik adalah musik yang memiliki unsur-unsur melodi, ritme, dan harmoni (Banoe, 2003: 288).

Sedangkan definisi musik menurut Bernstein \& Picker (dalam Djohan, 2006: 36) adalah suara yang diorganisir ke dalam waktu. Musik juga merupakan bentuk seni tingkat tinggi yang dapat mengakomodir interpretasi dan kreativitas individu. Sekelompok orang dalam kegiatan musik tidak pernah menunjukkan adanya dua orang yang mengekspresikan musik dengan cara yang mutlak sama.

Definisi tentang musik juga diungkapkan oleh Jamalus yang berpendapat bahwa musik adalah suatu hasil karya seni bunyi dalam bentuk lagu atau komposisi musik yang mengungkapkan pikiran dan perasaan penciptanya melalui unsur-unsur musik yaitu irama, melodi, harmoni, bentuk dan struktur lagu dan ekspresi sebagai satu kesatuan (dalam Muttaqin \& Kustap, 2008:3). 
Dari beberapa pendapat di atas yang mendefinisikan tentang musik, kemudian dapat ditarik kesimpulan bahwa musik adalah suatu hasil cipta manusia yang berisikan ide, pemikiran dan kreativitas yang dituangkan menjadi karya seni bunyi dalam bentuk lagu atau komposisi musik yang memiliki unsur-unsur seperti irama, melodi, harmoni, bentuk, dan struktur lagu dan ekspresi sebagai satu kesatuan.

Dalam sejarah perkembangan musik, di masa lalu musik dikaitan dengan dua fungsi pokok, yaitu sebagai sarana nemesis (Nemesis dari bahasa Yunani yang artinya transformasi dan imitasi dari luar ke dalam diri manusia) dan juga katarsis yang mengandung arti pemurnian jiwa melalui pengalaman emosional. Fungsi musik sebagai sarana nemesis dapat kita temukan dalam bentuk-bentuk pertunjukan opera sekitar abad ke-16 di Eropa. Seorang penyanyi opera tidak hanya dituntut untuk menguasai teknik vokal dengan sangat baik, tetapi juga dituntut untuk menjiwai tokoh yang diperankannya. Jadi, fungsi musik dalam opera adalah untuk merefleksikan emosi melalui kata-kata dan gerakan (Djohan, 2009: 86-87).

Fungsi musik sebagai sarana katarsis meyakini bahwa musik juga dapat menjadi sarana pengekspresian diri. Musik dianggap mempunyai kekuatan untuk menggugah emosi, yang dituangkan melalui penjiwaan terhadap alur cerita dan watak tokoh yang diperankan. Penjiwaan karakter dalam opera, misalnya akan terkait dengan berbagai macam ekspresi emosi yang tentu saja didukung oleh karya musik yang tepat seperti apakah pelaku sedang bermasalah, galau, ceria, percintaan dan lain sebagainya (87-88).

Merriam dalam bukunya The Anthropology Of Music menyatakan, terdapat 10 fungsi dari musik yaitu fungsi pengungkapan emosional, fungsi penghayatan estetis, fungsi hiburan, fungsi komunikasi, fungsi perlambangan, fungsi reaksi jasmani, fungsi yang berkaitan dengan norma sosial, fungsi kesinambungan budaya, dan fungsi pengintegrasian masyarakat. Oleh karena itu, fungsi musik adalah hal-hal yang berkaitan dengan ide-ide maupun perilaku suatu masyarakat (Merriam, 1964: 32-33).

Musik merupakan salah satu jenis bentuk seni pertunjukan. Pertunjukan adalah seni yang disajikan dengan tampilan peragaan, yaitu seni akan dapat dinikmati dan dihayati selama berlangsungnya ungkapan oleh pelaku seni (Bastomi, 1988:42). Oleh karena itu, pertunjukan musik adalah segala bentuk kreativitas seorang atau sekelompok musisi yang dituangkan ke dalam bentuk suatu pertunjukan yang dapat dipertontonkan kepada semua orang dalam bentuk seni musik sehingga ide, pemikiran, maupun kritik sosial yang musisi proyeksikan agar dapat dinikmati, diapresiasi, dan bermanfaat kepada orang banyak.

\section{Pertunjukan Musik dan Perkembangan Teknologi}

Seiring dengan berkembangnya kemajuan teknologi, hal ini memberi dampak negatif terhadap menurunnya minat masyarakat dalam menonton pertunjukan musik secara langsung. Penulis menemukan artikel yang berjudul "Jangan Salahkan Teknologi” yang membahas tentang hadirnya "new technology" yang menyebabkan terpuruknya industri musik. Dalam sebuah diskusi yang diadakan di San Fransisco Music Tech Summit, Lowery mempertanyakan apakah bisnis model digital yang baru akan lebih menguntungkan bagi para musisi. 
Dalam pandangannya, meskipun para artis musisi menjadwalkan tur dan roadshownya lebih banyak tahun ini dibandingkan dengan tahun-tahun sebelumnya, namun rupanya minat orang yang datang ke tempat pertunjukan musik cenderung menurun. Ia mengatakan bahwa hadirnya Youtube dimana orang-orang dapat menonton pertunjukan musik tanpa harus bersusah payah datang ke tempat konser diindikasikan merupakan salah satu faktor yang mempengaruhi turunnya minat seseorang menonton konser. Lebih lanjut David mengkritisi situs pencarian seperti Google yang telah menampilkan hasil pencarian berupa link ke situs ilegal. Meskipun Google juga telah menyediakan ruang pengaduan dengan DMCA, David memaparkan betapa mudahnya situs ini untuk diretas atau di crack (Ibid). Situs pencarian seperti Google juga merupakan salah satu faktor yang mempengaruhi menurunnya minat orang untuk menonton pertunjukan musik.

Selain Youtube dan situs pencarian Google lainnya, faktor adanya perusahaan rekaman yang mencetak lagu berupa fisik dan digital seperti kaset, CD, DVD, dan saat ini berkembang ke teknologi digital, Soundcloud, RBT dan Apple dengan iTunes-nya menyediakan aplikasi musik yang bisa mengunduh atau mendownload lagu secara online, juga membuat menurunnya apresiasi orang untuk datang menonton pertunjukan musik secara langsung.

Pada 2015 harian Kompas mengadakan jajak pendapat mengenai minat orang dalam mendengarkan dan menonton pertunjukan musik. Dari 734 responden, 1\% mendengarkan musik melalui pemutar kaset atau $\mathrm{CD}, 62 \%$ mayoritas responden kelompok muda lebih terbiasa menikmati musik melalui internet dengan cara mengunduh maupun mendengarkan secara langsung atau streaming. Selain itu, sekitar 15\% lainnya mengakses melalui laman Youtube. Hasil penelitian lainnya seperti, Global World Index menyimpulkan bahwa orang-orang mendengarkan musik lewat internet meningkat hingga 76\% selama periode 2012-2015. Data lain dari organisasi rekaman dunia Internasional Federation of Phonographic Industry (IFPI) mencatat 46\% pendapatan industri musik secara global pada tahun 2014 sudah dikuasai rekaman musik digital. Sementara itu, rekaman musik fisik sebesar, $46 \%$ dan $8 \%$ sisanya dari pertunjukan langsung.

Dari data-data yang telah dipaparkan di atas, penulis mengindikasi akan terjadinya masalah di tahun-tahun yang akan datang terkait matinya pertunjukan musik secara langsung. Semakin canggihnya teknologi akan membuat orang menjadi malas untuk pergi menonton pertunjukan musik secara langsung. Selanjutnya, interaksi antara musisi dan fans secara langsung di gedung konser tidak akan dijumpai lagi. Ciri manusia sebagai makhluk sosial akan bertransformasi menjadi mahluk individu yang semua aktivitasnya mengandalkan kemajuan teknologi. Hal ini merupakan masalah yang sangat penting untuk diperhatikan. Oleh karena itu, penulis bermaksud untuk meneliti lebih lanjut mengenai matinya pertunjukan musik sebagai akibat dari perkembangan teknologi.

Berdasarkan gambaran yang telah dijelaskan dalam bab pendahuluan di atas, terdapat dua rumusan masalah dalam penelitian ini: yang pertama, apa sajakah bentukbentuk penyebab matinya pertunjukan musik dilihat dari teori simulakra dari Jean Paul Baudrillard, dan yang kedua yaitu bagaimana efek simulakra terhadap pertunjukan musik.

Baudrillard (1929-2007) secara khusus memperhatikan fenomena konsumerisme masyarakat modern dan keterkaitannya dengan perkembangan media massa kontemporer. Baudrillard berpijak pada berbagai bentuk penolakan terhadap konvensi sosial, konsumsi 
berlebihan, dan pemikiran serta perilaku konvermis yang kesemuanya dapat menyatu dalam praktik perubahan radikal. Terdapat beberapa pemikiran Baudrillard yang terkenal dalam disiplin ilmu sosial-humaniora antara lain yaitu konsumsi simbol, simulakra, hiperrealitas, distingsi, sampah visual, dan drugstore.

Aspek Simulacrum atau simulakra merupakan suatu bentuk instrumen atau alat yang mampu merubah hal-hal yang bersifat abstrak menjadi kongkret, begitu juga sebaliknya yaitu dari kongkret menjadi abstrak. Sebagai contoh instrumen Simulakra menurut Baudrillard yaitu televisi, video games, komputer atau internet, surat kabar dan majalah, bahkan lukisan. Contoh simulakra dalam merubah suatu hal yang kongkret menjadi abstrak yaitu film. Sebagaimana kita ketahui bahwa manusia yang senyatanya berwujud kongkret dapat diubah sedemikian rupa ke dalam televisi atau layar dan berubah menjadi abstrak. Sedangkan contoh perubahan dari suatu hal yang abstrak menjadi kongkret yaitu film kartun yang dimana dalam keadaan sehari-hari pada realitasnya tidak kita temukan kehidupan kartun karena semuanya merupakan khayalan dan abstrak, namun dalam layar kaca kehidupan kartun itu seolah-olah nyata. Seperti itulah cara simulakra bekerja.

Dalam kata pembuka bukunya Simulacres et simulation (1981), Baudrillard mengutip dari kitab Ecclesiaste untuk mendefinisikan simulacrum. "Simulacrum tidak pernah merupakan sesuatu yang menyembunyikan kebenaran - namun kebenaran yang menyembunyikan bahwa tidak ada apa-apa. Simulacrum menurut Baudrillard, tidak pernah bisa ditukar dengan realitas, tetapi saling menukar dengan dirinya sendiri, dalam suatu lingkaran tak terputus yang tidak membutuhkan acuan (Baudrillar dalam Haryatmoko, 2016: 70).

\section{Metode Penelitian}

Dalam penelitian ini penulis memperoleh dan mengumpulkan data dengan dua cara, yaitu pengumpulan data melalui internet dan pustaka. Untuk pengumpulan data melalui internet, penulis mencari semua data yang diperlukan terkait dengan topik penelitian dan fenomena-fenomena yang terjadi di masyarakat melalui internet dengan cara masuk ke indeks atau pangkal data yaitu Ebsco karena mengandung berbagai jurnal humaniora yang diperlukan dalam penelitian ini. Kemudian, penulis memasukkan tiga kata kunci pencarian menggunakan asas Boolean yaitu musik, pertunjukan musik, dan simulakra. Untuk pengumpulan data melalui pustaka, penulis mencari buku yang sesuai dengan topik penelitian ini dan relevan untuk dijadikan data acuan maupun tambahan.

Kemudian data dari sumber yang diperoleh baik melalui internet maupun pustaka, penulis melakukan empat teknik untuk mengumpulkan data yaitu melalukan pembacaan (reading), pencatatan (note taking), penginterpretasian (interpreting), dan pengelompokan (clustering). Penulis membaca jurnal, blog, maupun buku yang menunjang penelitian yang diperoleh dari kedua sumber kemudian mencatat dan menggarisbawahi data-data berupa informasi yang penting yang diperlukan untuk penelitian kemudian menginterpretasikannya sesuai dengan masalah dalam penelitian. Setelah itu, penulis melakukan pengelompokan data atau pemilahan data dengan cara mengambil data yang hanya diperlukan dalam penelitian dan membuang data yang tidak relevan (data reduction). 
Dalam proses ini, penulis mengelompokkan data menjadi tiga bagian, yaitu musik, pertunjukan musik, dan simulakra. Semua data yang penulis ambil bersumber dari bahan bacaan dengan mengacu pada tahun penulisan setidaknya lima tahun terakhir terhitung dari tahun penelitian yang sedang dilakukan agar didapatkan referensi yang mutakhir dan terdapat keterbaharuan dalam pemikiran dan analisa.

\section{Hasil dan Analisis}

\section{Bentuk-bentuk Matinya Pertunjukan musik}

\section{Bentuk Fisik: Kaset dan VCD}

Dalam kasus matinya pertunjukan musik, teori simulakra ini dapat dilihat dari munculnya industri perekaman musik yang mencetak lagu-lagu ke dalam bentuk fisik seperti kaset, CD, dan DVD. Simulasi memang bukan lagi masalah meniru atau membuat duplikatnya, bukan pula suatu bentuk parodi, tapi masalah menggantikan tanda-tanda riil yang kemudian justru diperlakukan seakan sebagai yang riil itu sendiri. Simulasi merupakan bentuk operasi untuk mencegah setiap proses riil agar tidak diganti oleh duplikatnya yang operasional. Hal ini merupakan bentuk simulasi yang dibuat para pelaku industri untuk dapat menghasilkan keuntungan yang sebesar-besarnya dengan cara yang seefisien mungkin jika dibandingkan dengan hasil laba atau keuntungan jika menyelenggarakan pertunjukan musik secara langsung yang akan membutuhkan banyak biaya. Dengan dicetaknya bentuk simulasi berupa kaset, CD, dan DVD, seakan mereka mau menggantikan pertunjukan musik dengan bentuk lain, artinya penikmat musik tidak perlu repot lagi datang menonton pertunjukan musik secara langsung dengan mendengarkan musik di kaset, CD, dan DVD orang akan sudah terpuaskan hasratnya dan tidak perlu lagi menonton pertunjukan musik. Jadi, simulasi menjadi mesin programatik dan deskriptif sempurna yang menyediakan semua tanda riil untuk memberi jalan pintas semua perubahannya.

Bentuk simulakra lain dari pelaku industri musik yaitu para pelaku hanya perlu menyelenggarakan satu kali proses pertunjukan musik dan atau mengadakan satu kali proses perekaman musik untuk kemudian dikemas dan dicetak ke dalam bentuk media yang lebih sederhana seperti kaset, CD, dan DVD. Proses penyederhanaan ini tentu saja menghemat biaya. Contohnya seperti biaya tenaga kerja, misalkan jika dalam pertunjukan musik secara langsung diperlukan jumlah tenaga kerja atau crew yang terlibat dalam pementasan pertunjukan musik tentunya tidak sedikit dan memerlukan banyak biaya. Namun jika pertunjukan musik disederhanakan ke dalam bentuk kaset, CD dan DVD dengan cara perekaman maka akan menghemat banyak biaya karena proses produksinya hampir sebagian besar dilakukan oleh mesin. Tentu saja dengan menggunakan sedikit bahan mentah, sederhana dalam pembuatan dan penyajiannya akan tetapi dapat dengan segera atau cepat dikonsumsi atau dinikmati oleh konsumen.

Namun, konsumsi ini juga mendorong orang menjadi individualis, karena pemenuhan hasrat akan suatu barang atau jasa lebih untuk kebutuhan diri sehingga mengikis solidaritas karena dengan adanya simulasi dalam produksi industri dari pertunjukan musik langsung ke dalam bentuk kaset, CD, dan DVD maka para penikmat 
musik atau konsumen seolah-olah dapat menikmati pertunjukan musik melalui media tersebut di atas. Para konsumen tidak lagi dapat menikmati indahnya pertunjukan musik secara langsung karena merasa kenikmatan musik itu sendiri telah didapatkan melalui memutar media seperti kaset, CD, dan DVD. Hal ini dapat mengakibatkan kematian pada pertunjukan musik di kemudian hari karena para penikmat musik atau konsumen tidak lagi memerlukan pertunjukan musik sebagai bentuk hiburan, karena telah tergantikan dengan kemajuan teknologi.

\section{Bentuk Digital: iTunes dan download}

Perkembangan teknologi membuat industri perekaman merupakan model sempurna dalam tatanan simulasi dimana dikembangkan dengan memberikan kemudahan manusia dalam mengaksesnya dengan cepat dan mudah. Dalam kasus matinya pertunjukan musik, sehubungan dengan majunya perkembangan teknologi, salah satu faktor penyebabnya adanya industri perekaman musik yang mencetak lagu-lagu ke dalam bentuk digital seperti iTunes.

iTunes merupakan salah satu dari produk dari perusahaan raksasa teknologi Apple. Dengan adanya layanan aplikasi ini para penggunakan iPhone dapat membeli dan mendownload musik dan produk digital lainnya dengan cepat dan mudah. Kemudahan ini dijadikan alasan bagi para pemilik modal bahwa iTunes telah memberikan kontribusi sebesar-besarnya untuk keuntungan perusahaan. Sejak aplikasi iTunes di luncurkan, Apple telah menjual lebih dari 10 miliar lagu. Bentuk Daya Hitung inilah yang digunakan para pemilik modal untuk mampu menghitung segala keuntungan dengan perhitungan yang telah dipersiapkan. Contohnya jika konsumen mengunduh satu lagu, maka mereka harus membayar $\mathrm{Rp}$ 7.000; dan dikalikan dengan jumlah semua pengunduh seluruh dunia, maka hasilnya dapat dihitung sesuai dengan prediksi.

Dengan adanya iTunes, para pemilik modal dapat menghitung beban biaya produksi mereka. Contohnya, dengan iTunes, para pemilik modal akan lebih menghemat biaya dari yang sebelumnya menggunakan bahan mentah seperti material kaset, CD, dan DVD, kini mereka tidak perlu lagi mengeluarkan beban biaya-biaya tersebut. Para konsumen cukup mengkoneksikan iphone atau gadget mereka dengan internet dan mengunduh lagu-lagu favorit mereka. Oleh karena itu, dunia imajiner memungkinkan keberhasilan simulasi berkat adanya kesenangan, kemudahan, dan kecepatan dalam men-download atau mengakses produk yang diinginkan. Mesin ini membuat dunia manusia seakan-akan berada di tempat pertunjukan musik, yaitu dunia riil, padahal mesin-mesin di iPhone itu digunakan untuk menarik keuntungan sebesar-besarnya oleh pelaku industri dan pemilik modal.

\section{Efek Simulakra terhadap Pertunjukan Musik}

Baudrillard menjelaskan tentang simulakra sebagai suatu bentuk instrumen atau alat yang mampu merubah hal-hal yang bersifat abstrak menjadi kongkret, begitu juga sebaliknya yaitu dari kongkret menjadi abstrak. Seperti yang telah dijelaskan diatas bahwa terdapat bentuk-bentuk matinya pertunjukan musik seperti bentik fisik (kaset, CD, dan DVD) serta bentuk digital (iTunes). Bentuk-bentuk tersebut merupakan simulakra 
dalam pengertian Baudrillard sebagai instrumen pengganti yang mampu merubah hal-hal yang bersifat abstrak menjadi konkret atau sebaliknya.

Kemudian dalam perkembangan teknologi, dengan adanya bentuk-bentuk simulakra yang berupa kaset, $\mathrm{CD}, \mathrm{VCD}$, dan iTunes membuat para pelaku industri musik, dalam hal ini para pemilik modal, dapat dengan mudah mendapatkan keuntungan sebesar-besarnya dan menghemat berbagai biaya-biaya proses produksi. Efek yang dihasilkan dari alat-alat atau instrumen simulakra ini yaitu membuat konsumen, dalam hal ini manusia, tidak lagi dapat berinteraksi dengan sesama manusia karena lebih banyak menghabiskan waktu mereka dengan teknologi. Manusia merasa dengan adanya industri perekaman yang dikemas dalam bentuk fisik seperti; kaset, CD, dan DVD yang kemudian dikembangkan ke dalam bentuk digital seperti; Youtube, RBT, dan iTunes mereka seolah-olah mereka sudah mendapatkan kepuasan yang sama selayaknya menonton pertunjukan musik secara langsung. Hal ini menjadi irasional karena manusia tidak dapat berfikir bahwa kemajuan teknologi berupa kaset dan sebagainya merupakan topeng dari para pemilik modal untuk menghemat biaya produksi mereka.

Efek simulakra selanjutnya yaitu manusia menjadi target dari pemilik modal untuk mendapatkan keuntungan. Selain itu, manusia menjadi sasaran para pemilik modal untuk menerapkan idealisme mereka tentang standarisasi dan penyeragaman selera secara massal melalui kaset, CD, dan DVD, Youtube, RBT, dan iTunes. Hal ini membuat manusia kehilangan akal atau rasional mereka karena bentuk-bentuk simulakra tersebut sejatinya mengontrol pola pikir, perilaku, kegiatan serta selera mereka dalam kehidupan sehari-hari.

Efek irrasionalisasi ini membuat manusia kehilangan interaksi dengan manusia yang lain. Contohnya manusia tidak lagi menonton pertunjukan musik yang dipertunjukan manusia secara langsung, dan digantikan oleh mesin berupa kaset, $\mathrm{CD}, \mathrm{VCD}$, Youtube, $R B T$, dan iTunes. Hal yang sama juga terjadi pada para musisi yang akhirnya tidak mampu berinteraksi lagi dengan penggemarnya karena karya mereka sudah tidak diperdengarkan lagi secara langsung atau berkurangnya kesempatan mereka dalam melakukan pertunjukan musik, maka matilah pertunjukan musik mereka. Dampak terburuk dari bentuk-bentuk simulakra ini adalah manusia saat ini dan pada akhirnya dikhawatirkan akan kehilangan fungsi dan sifat manusia itu sendiri, dalam contoh penelitian ini, manusia yang sejatinya menikmati musik melalui pertunjukan musik, sekarang berubah menjadi pola menikmati musik melalui kaset, $\mathrm{CD}, \mathrm{VCD}$, Youtube, RBT, dan iTunes dan kepuasan yang mereka dapatkan seolah-olah sama seperti mendengarkan musik melalui pertunjukan musik. Hal ini kemudian menjadikan interaksi antara manusia satu dengan lainnya menjadi berkurang dan akan mengakibatkan adanya dehumanization atau manusia akan kehilangan kodratnya sebagai manusia.

\section{Kesimpulan}

Alat-alat atau instrumen simulakra seperti kaset, $\mathrm{CD}$, VCD, Youtube, RBT, dan iTunes merupakan sistem yang diciptakan oleh kaum kapitalis untuk dapat menguasai pasar dan menciptakan standarisasi atau penyeragaman berupa penyeragaman produk, selera, serta membentuk kebiasaan dan perilaku konsumen untuk mengikuti kontrol para 
pemilik modal. Mendengarkan musik melalui kaset, $\mathrm{CD}$, DCD, dan iTunes, membuat para konsumen sejatinya dijauhkan dengan nilai-nilai kemanusiaan itu sendiri dengan dalih efisien, praktis, maupun atas nama modernitas.

Dengan perilaku dan kebiasaan mendengarkan musik lewat media-media seperti yang telah disebutkan di atas, maka akan membawa efek dalam pertunjukan musik. Interaksi antara musisi dengan penggemar akan mati karena penggemar sudah tidak menonton pertunjukan secara langsung, senada dengan itu, para musisi juga tidak lagi dapat berinteraksi dengan para penggemar karena karya-karya mereka sudah tersedia dalam format kaset, CD, DVD, dan iTunes. Oleh karena itu, kita buktikan dalam beberapa tahun mendatang apakah teori Baudrillard tentang simulakra ini terbukti atau tidak dalam segi pertunjukan musik dengan melihat berbagai fenomena saat ini yang manusia sudah kehilangan sifat atau nature manusia itu sendiri yang akan mengarah pada dehumanisasi.

\section{Kepustakaan}

Banoe, Pono. 2003. Kamus Musik.Yogyakarta: Kanisius.

Bastomi, S. 1988. Apresiasi Kesenian Tradisional. Semarang: IKIP Semarang Press. Djohan. 2006. Terapi Musik: Teori dan Aplikasi. Yogyakarta: Galangpress. 2009. Psikologi Musik. Yogyakarta: Best Publisher.

Haryatmoko. 2016. Membongkar Rezim Kepastian Pemikiran Kritis Post-Strukturalis. Yogyakarta: Kanisius

Kustap, Muttaqin. 2008. Seni Musik Klasik Jilid 2. Jakarta: Direktorat Pembinaan Sekolah Kejuruan.

Merriam, Alan P. 1964. The Anthropology of Music. Chicago Nortwestern University.

\section{SUMBER DARI INTERNET}

http://www.widiasmoro.com/2012/04/23/jangan-salahkan-teknologi/,diakses pada tanggal 5 Juni 2016 pukul 18.19 WIB.

http://print.kompas.com/baca/2016/01/05/Industri-Musik-Redup-oleh-Digital, diakses pada tanggal 5 Juni 2016 pukul 20.40 WIB.

http://www.ifpi.org/global-statistics.php, diakses pada tanggal 7 Juni 2016 pukul 18.30 WIB.

http://www.plimbi.com/article/3154/lebih-dekat-dengan-iTunes-pada-perangkat-apple, diakses pada tanggal 9 juni 2016 pukul 18.05 . 